\title{
Estimation of Tree Carbon Stocks in the Green Open Space of the Faculty of Forestry, Tanjungpura University
}

\author{
Yonatan Ng, Dwi Astiani*, Hanna Artuti Ekamawanti \\ Faculty of Forestry, Tanjungpura University. Jl. Daya Nasional, Pontianak, 78124, Kalimantan Barat, Indonesia \\ * Corresponding Author. E-mail address: astiani.dwi@gmail.com
}

\section{ARTICLE HISTORY:}

Received: 17 January 2021 Peer review completed: 15 September 2021 Received in revised form: 19 September 2021 Accepted: 8 November 2021

\section{KEYWORDS:}

Allometric equation Biomass

Carbon stocks

Green open space

(C) 2021 The Author(s). Published by Department of Forestry, Faculty of Agriculture, University of Lampung in collaboration with Indonesia Network for Agroforestry Education (INAFE) This is an open access article under the CC BY-NC license:

https://creativecommons.org/licenses/by nc/4.0/.

\begin{abstract}
The presence of green open space containing vegetation in urban areas plays a vital role in absorbing and storing carbon in biomass. Tanjungpura University (Untan) Pontianak has a green open area in the New Building of the Faculty of Forestry. This study aimed to describe carbon reserves stored in biomass above ground level (vegetation) in green open areas around the New Building of Faculty of Forestry Untan Pontianak. Data were collected using an inventory survey by non-destructive sampling, which includes recording with fully enumerated data collection on the type and diameter of trees with a continuous line plot system. The data were then analyzed using allometric equations to obtain biomass values. The results found as many as 56 species of trees with a total of 558 individuals dominated by Litsea garciae and Hevea brasiliensis. The results showed the amount of carbon stored at the tree level of 59.06 tons/ha (76.18\%), pole level of 13.94 tons/ha (17.99\%), and sapling level of 4.52 tons/ha $(5.83 \%)$, with an average carbon stock of 77.52 tons/ha. Thus, the green open area could store 148.53 tons of carbon in tree biomass. Although it is a small area, this peatland ecosystem could accumulate peat in organic soil and its vegetation and should be managed as peatland forests. Therefore, proper management is essential, and hydrology management is needed mainly due to its nature.
\end{abstract}

\section{Introduction}

Global warming is a process of increasing the earth's temperature caused by an increase in greenhouse gas concentration in the atmosphere. The surge of greenhouse gasses in the global atmosphere is mainly due to anthropogenic forces (Arto and Dietzenbacher 2014; Delworth et al. 2016). One of the greenhouse gases that contribute greatly to global warming is carbon dioxide $\left(\mathrm{CO}_{2}\right)$, whose composition reaches $75 \%$ in the atmosphere (Holdaway et al. 2014; Keith et al. 2018). This carbon concentration can be suppressed through the carbon sequestration process (Santori et al. 2018). Trees in forests could absorb $\mathrm{CO}_{2}$ for photosynthesis and store it in the form of carbohydrates in pools within roots, stems, and leaves before being released into the atmosphere through the carbon cycles. These create a link between forest biomass and carbon content (Bustammante et al. 2016). The activity of measuring the amount of carbon stored in the body of living plants (biomass) on the above and below ground can describe the amount of $\mathrm{CO}_{2}$ in the atmosphere absorbed by plants.

Vegetation is a natural engine for absorbing and storing carbon and producing oxygen. Therefore its existence is essential, especially in efforts to mitigate the effects of greenhouse gases. Unfortunately, the existence of vegetation is often neglected and sometimes even eliminated by 
the development process, as is the case in urban areas (Luo et al. 2015). Carlson et al. (2012) and Houghton et al. (2012) stated that the conversion of forests to other uses triggered the release of large amounts of carbon into the atmosphere. Green open space is one solution for reducing greenhouse gases in urban areas (De Villiers et al. 2014; Tang et al. 2016). Manuri et al. (2014) mentioned that the provision of green open space is part of mitigating global warming; hence it is considered as one of the most implementable efforts to address the increase in greenhouse gas emissions, especially $\mathrm{CO}_{2}$, compared to other methods. The Indonesian Minister of Public Works and Housing Regulation No. 5 of 2008 stated that the ideal area of green open space in an urban area should be $30 \%$ of the city's total area, consisting of $20 \%$ public green open space and $10 \%$ private space one.

Tanjungpura University (Untan) Pontianak also has some green open spaces, one of which is found in the New Building of the Faculty of Forestry. This area is certainly a part of the green space which is very beneficial for environmental health and the production of fresh air surrounding Untan. An interesting finding on green space in campus study showed that it could effectively improve student health and concentration, especially for students who infrequently go outside (Ibes and Forestell 2020).

The green open space in the New Building of the Faculty of Forestry Untan Pontianak is unique. Apart from being a green open area, it is also a type of degraded tropical peat swamp forest with a peat depth of 50-200 cm, which is rare to find in green open spaces on campus. Importantly, similar to a larger forested area, this green space has been sequestering and stocking carbon within the vegetation biomass. However, the amount of carbon stored is still a knowledge gap to exhibit its role and function for the environment. Therefore, this study aims to estimate the carbon stock stored in aboveground biomass (vegetation) in the green open space around the New Building of the Faculty of Forestry Untan Pontianak. This study is expected to describe the capability of the space to store and sequester carbon and is expected as a basis for consideration in the management and preservation of the green open space of the Untan area.

\section{Materials and Methods}

\subsection{Study Site}

The study was conducted in small patches of the green area of the New Building Faculty of Forestry, Tanjungpura University in Pontianak. The soil type is shallow organosol or peatland $(0.5-1 \mathrm{~m})$, which grows a peat forest ecosystem. The area has been encroached by the local community, where they plant rubber trees before the new building is established. The Faculty of Forestry recently managed the land space.

The study site was limited to the forest between the Forestry Faculty and the Teaching and Education Faculty to the forest behind the Forestry Faculty canteen (Fig. 1). Geographically, the new building of the Faculty of Forestry, Tanjungpura University, is located at the coordinate point $00^{\circ} 03$ ' 38.32" S, $109^{\circ} 20^{\prime} 31.05^{\prime \prime} \mathrm{E}$, with area boundaries are as follow:

- North: Boundary of Teacher Training and Education Faculty,

- South: Jalan Reformasi Pontianak,

- East: Boundary of Faculty of Economics and Business,

- West: Jalan Perdana Pontianak. 


\subsection{Materials}

The equipment used in this study was a map of the research location, global positioning system (GPS) tracker, diameter tape (phi band), $1.3 \mathrm{~m}$ measuring stick, compass, meter, rope, identification book, tally sheet, tree label, and camera for documentation. The object of research was standing trees with a diameter of $>5 \mathrm{~cm}$.

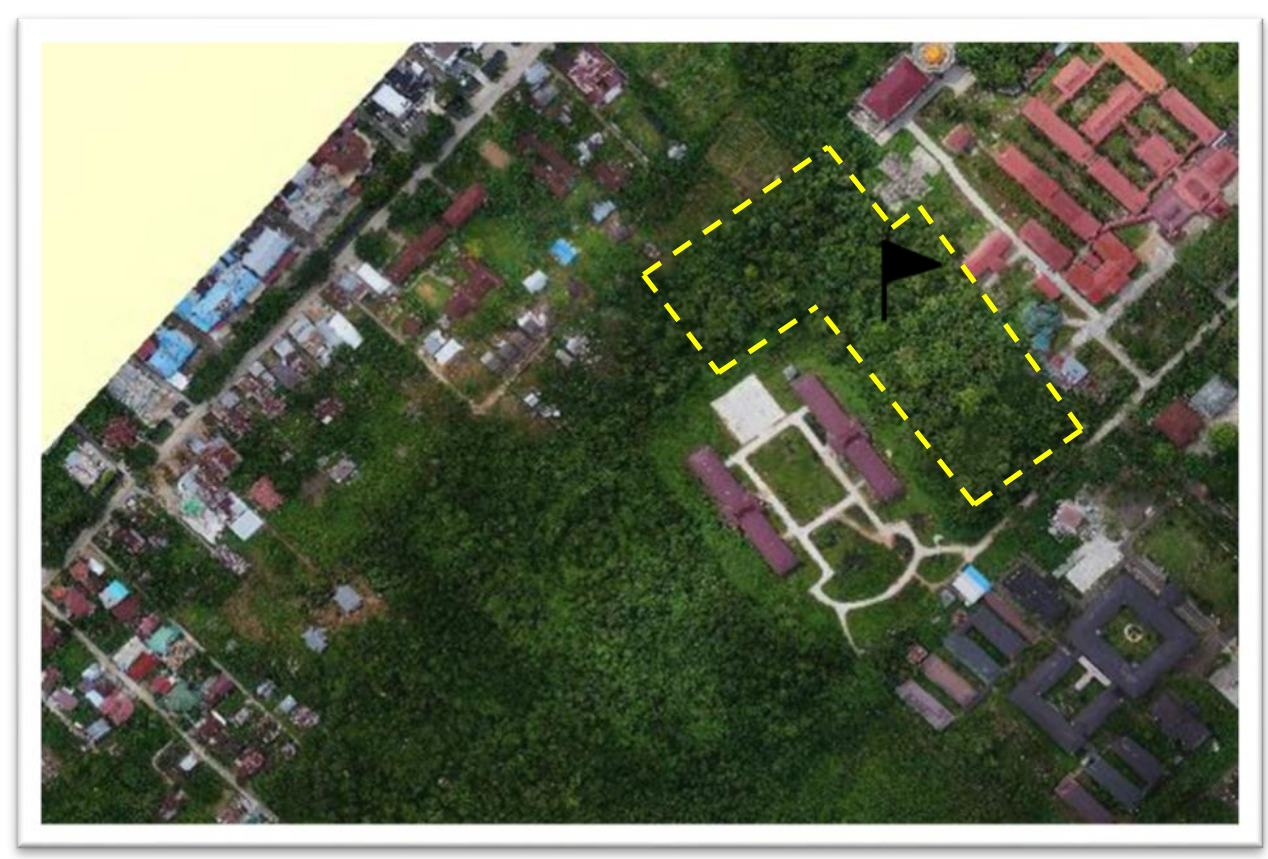

Fig. 1. The study site is inside the green dot line.

\subsection{Sampling Methods}

This study used an inventory survey method with non-destructive sampling for trees, including recording species and measuring tree diameter at breast height in a compartmental path. The measurement of tree-level diameter (D) was carried out as a whole (census), while the growth rate measurement of poles and saplings was carried out by sampling using nested plots. The size of the plots at tree level $(\mathrm{D} \geq 20 \mathrm{~cm})$ was $20 \mathrm{~m} \times 20 \mathrm{~m}$, pole level $(\mathrm{D}=10-19.9 \mathrm{~cm})$ was $10 \mathrm{~m} \mathrm{x}$ $10 \mathrm{~m}$, and sapling level $(\mathrm{D}=5-9.9 \mathrm{~cm})$ was $5 \mathrm{~m} \times 5 \mathrm{~m}$. The plots were placed every $30 \mathrm{~m}$ on the line axis. The shape of the plot and the length of the research path were adjusted to the location area (Fig. 2).

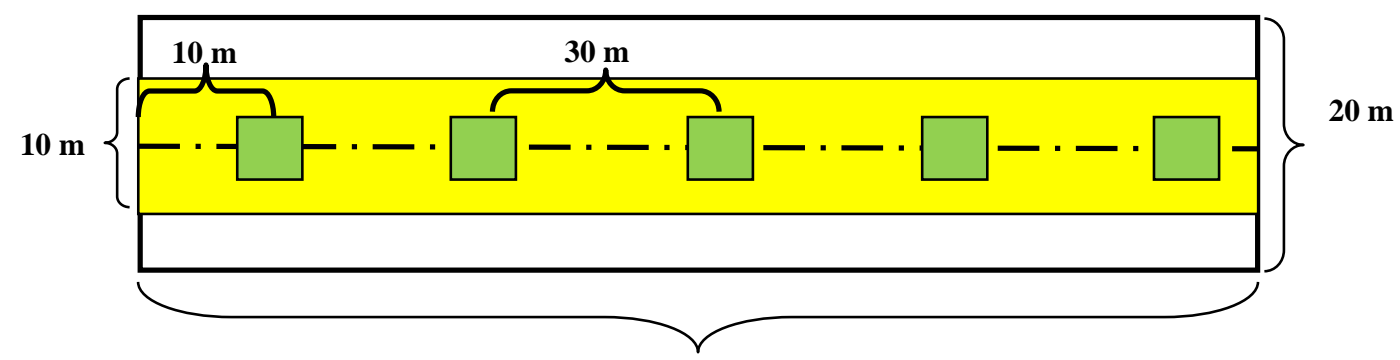

The transect length varies depending on the area perimeter within the green space of the Faculty of Forestry,

Tanjungpura University

Notes:

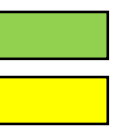

Plot size $5 \mathrm{~m}$ x $5 \mathrm{~m}$ for sapling stage assessment

Continues plot assessment for tree and pole stage

Fig. 2. Plot arrangement within the study site. 
The number of individual trees found in the observation plots for each growth rate was also calculated. Species identification found in the observation plots was identified based on a tree identification book and assisted by a tree identifier.

\subsection{Data Collection}

Tree diameter was measured on breast height $(\mathrm{DBH})$, which is $1.3 \mathrm{~m}$, and for trees that are not normal, it was measured with reference to Fig. 3.

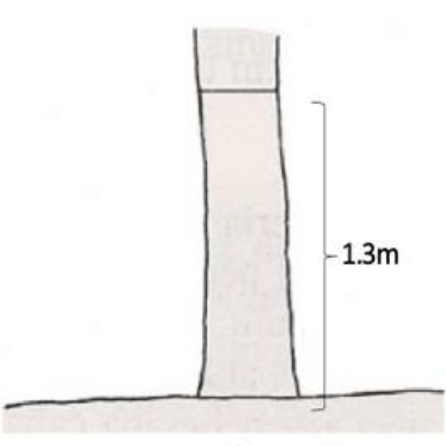

a

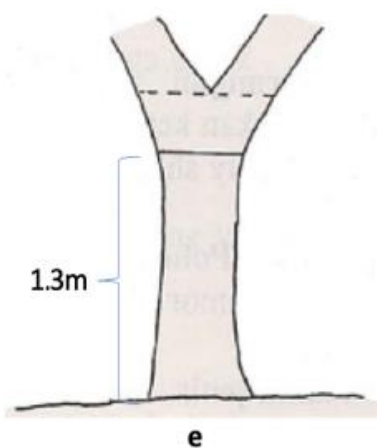

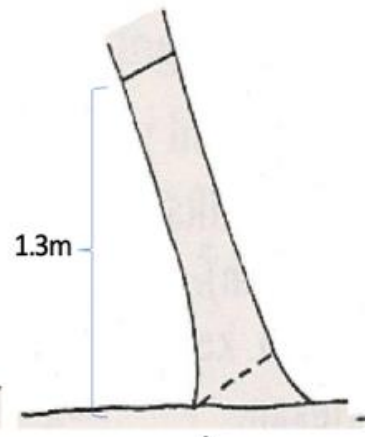

b

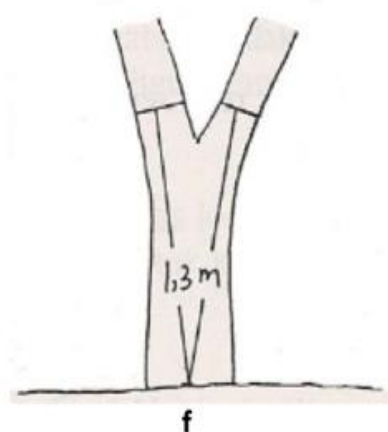

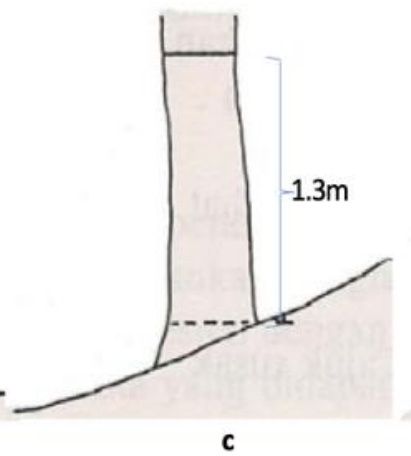

c

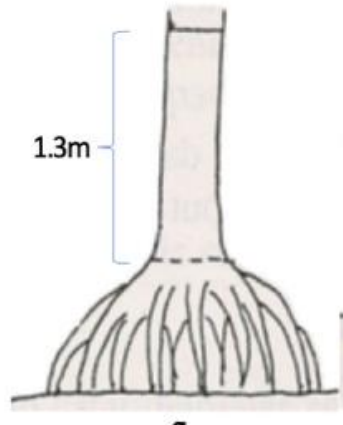

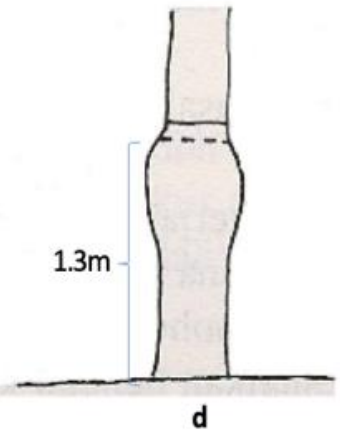

d

Fig. 3. The rule for determining the tree's DBH measurement (Manuri et al. 2011).

Notes:

a. For normal trees, DBH is measured $1.3 \mathrm{~m}$ from the surface of the ground

b. For sloping trees, DBH is measured $1.3 \mathrm{~m}$ from the nearest ground level or in the direction of the tree's slope

c. Normal trees on sloping DBH soil are measured $1.3 \mathrm{~m}$ from the highest ground level

d. Defective tree, if $1.3 \mathrm{~m}$ is right on the defective stem (swollen), DBH is measured at the limit of the part that starts to normal, above or below depending on the nearest

e. For a tree branch, if $1.3 \mathrm{~m}$ is right at the beginning of the branch, DBH is measured at the bottom of the branch, which is still normal

f. For a tree branch, if 1.3 meters above the branch, measure the DBH on both branches and assume two stems

g. For supporting root trees, DBH is measured $1.3 \mathrm{~m}$ from the upper limit of the supporting roots

h. Tree with buttresses and mangroves, DBH is measured at $20 \mathrm{~cm}$ from the edge of the buttress.

\subsection{Biomass and carbon Calculation}

Biomass is calculated based on tree diameter and wood density data using the allometric equation following Chave et al. (2005).

$$
A G B_{\text {est }}=\rho * \exp \left(-1.499+2.148 * \ln (D)+0.207 *\left(\ln (D)^{2}-0.0281 *\left(\ln (D)^{3}\right)\right.\right.
$$

where $A G B$ est is above ground biomass ( $\mathrm{kg} /$ tree), $D$ is tree diameter $(\mathrm{cm}), \rho$ is wood specific density $\left(\mathrm{g} / \mathrm{cm}^{3}\right)$. 
The total biomass of each growth level (saplings, poles, and trees) was calculated using Equation 2:

Total biomass $=A G B_{1}+A G B_{2}+\ldots . .+A G B_{n}$

The biomass per unit area (ton/ha) of each growth level was calculated using Equation 3:

$$
\text { Biomass }=\frac{\text { Total Biomass }}{\text { total area }}
$$

The amount of carbon is calculated based on the biomass data that has been obtained. The carbon estimate is calculated based on the carbon calculation formula following SNI 7724 (BSN 2011).

Total Carbon $=B x \%$ carbon

where B is total biomass $(\mathrm{kg})$, and \% carbon is the percentage value of carbon content $(47 \%)$. Furthermore, the calculation of carbon dioxide is converted by the time of the $\mathrm{CO}_{2}$ with 3.667.

\section{Results and Discussion}

\subsection{Estimation of Total Biomass and Carbon}

The sampling area for tree, poles, and sapling growth levels were 1.92, 0.96, and 0.07 ha, respectively. The biomass and carbon content at each growth stage can be seen in Table 1. The largest amount of biomass content per unit area was found at the tree stage, and the lowest amount of biomass was indeed at the sapling stage.

Table 1. The amount of biomass and carbon stocks at trees, poles, and sapling growth stage in the green open areas of the New Building of the Faculty of Forestry, Tanjungpura University

\begin{tabular}{|c|c|c|c|c|c|c|c|}
\hline Growth Stage & $\begin{array}{c}\text { Biomassa } \\
(\mathrm{kg})\end{array}$ & $\begin{array}{c}\text { Mean } \\
\text { Biomass per } \\
\text { ha } \\
\text { (ton/ha) }\end{array}$ & $\begin{array}{c}\text { Total } \\
\text { Biomass in } \\
\text { the study } \\
\text { area } \\
\text { (ton)* }\end{array}$ & SNI & $\begin{array}{c}\text { Mean } \\
\text { Carbon } \\
\text { (Ton/Ha) }\end{array}$ & $\begin{array}{l}\text { Total C } \\
\text { (Ton)* }\end{array}$ & $\underset{\left(\mathrm{CCO}_{2}\right)^{* *}}{\mathbf{C O}_{2-\mathrm{e}}}$ \\
\hline Tree & $240,740.70$ & 125.65 & 240.74 & 0.47 & 59.06 & 113.15 & 415.26 \\
\hline Pole & $28,420.92$ & 29.67 & 56.84 & 0.47 & 13.94 & 26.72 & 98.06 \\
\hline Sapling & 673.19 & 9.62 & 18.43 & 0.47 & 4.52 & 8.66 & 31.78 \\
\hline Total & $269,834.81$ & 164.93 & 316.01 & & 77.52 & 148.53 & 545.11 \\
\hline
\end{tabular}

The amount of carbon stored in the green space is relatively reasonable and sufficient to create a different microclimate than outside. Astiani et al. (2017) found that natural peat swamp forest in Kuala Dua Kubu Raya Village stored 55 to 120 tons C per ha, from heavily degraded to low degraded forest conditions. Heriyanto et al. (2020) reported that old secondary peat forest in South Sumatera stored less carbon (55 to 120 tons and $90.75 \mathrm{C} /$ ha consecutively) than the results of this study, while Erly et al. (2021) measured higher carbon (277.64 ton C/ha) in the low land forest of Bukit Barisan. However, the Intergovernmental Panel on Climate Changes recommended that a minimum limit of carbon stock in primary, secondary, and agroforestry forest lands are 138 tons C/ha (IPCC 2014). The carbon stock in the green open space is still low or below the minimum limit recommended by the IPCC but higher than the heavily degraded natural peat swamp forest. This study also demonstrated that the largest amount of carbon stock in tons is at the tree stage $(76.18 \%)$, and the rest were saved at the pole stage (17.99\%) and sapling stage $(5.83 \%)$ of the total 
carbon stocks. Asner and Mascaro (2014) mentioned trees with a larger basal area can store more carbon because the main contribution of biomass is in the trunk.

This small forest area needs to be maintained because the benefits are greater for the environment. Its significant function in reducing anthropogenic $\mathrm{CO}_{2}$ emissions generated from campuses or cities can be offset by conserving or increasing stored carbon (C) (Tang et al. 2016). The degradation of peatland forests could severely impact the environment, particularly the emission of carbon into the atmosphere. Enrichment planting with suitable species and maintaining present vegetation can increase the ability of these areas to both store and sequester carbon. Moreover, the peatland forest itself stores a significant amount of carbon within peat soil biomass below ground (Kurnianto et al. 2014; Leng et al. 2019). Thus, mismanagement of the peatland area will impact more $\mathrm{CO}_{2}$ emissions from the peat soil (Astiani et al. 2018).

The amount of carbon stocks of the green space, albeit in very small quantities, contributes to mitigating GHG emissions. The value of carbon stocks can be converted to $\mathrm{CO}_{2}$ by multiplying total carbon (tons) by 3.67. The results showed that the $\mathrm{CO}_{2}$ absorbed within the vegetation was 545.11 tons of $\mathrm{CO}_{2}$, and the carbon will be maintained within the vegetation biomass and enhanced as long as they are not died or disturbed. Therefore, this green space plays an important role in reducing greenhouse gases from the atmosphere. Peatland ecosystem, such as this area which accumulated peat, organic soil, and vegetation should be managed as peatland forests, even though its location within the campus environment. Some environmental factors that could influence the peat carbon stocks, i.e., changes in temperature, precipitation or rainfall, atmospheric composition, and fire (Leng et al. 2019). Therefore, proper peatland management is essential, particularly due to its nature, hydrology management is needed (Bispo et al. 2016; Waddington et al. 2015).

\subsection{Comparison of Tree Biomass among Allometric Models}

Tree biomass was calculated using different allometric models to compare the biomass produced from each allometric model. The allometric model used is adjusted to the type of ecosystem in the green space of the New Building of Faculty of forestry Untan, peatland forest. Based on the West Kalimantan Forest Reference Emission Level (FREL) report compiled by Hardiansyah et al. (2016), several allometric models can be used for peatland forest that has been considered through the allometric selection stage. Information about the biomass among allometric models can be seen in Table 2.

The results show that the biomass generated from each allometric model has varying values. According to Krisnawati et al. (2012), this significant diversity of tree biomass estimates, apart from differences in the allometric models used, is also due to differences in diameter size, floristic composition, species, and growth rates in each type of ecosystem that contribute to biomass development. The biomass results from the allometric test comparison can be seen in Table 3. It shows that the highest total biomass per hectare is found in the allometric model of Manuri et al. (2013), followed by Chave et al. (2005) and Jaya et al. (2007), and the lowest biomass yield is in the allometric model of Brown et al. (1997). 
Table 2. Comparison of tree biomass allometric equation of peatland forests

\begin{tabular}{|c|c|c|c|c|c|}
\hline Source & Allometric Model & $\begin{array}{l}\text { DBH } \\
(\mathbf{c m})\end{array}$ & $\mathbf{R}$ & Location & $\begin{array}{c}\text { Amount } \\
\text { of Sample }\end{array}$ \\
\hline $\begin{array}{l}\text { Chave et al. } \\
\text { (2005) }\end{array}$ & $\begin{array}{l}A G B_{e s t}=\rho^{*} \exp (- \\
1.499+2.148 * \ln (D)+ \\
0.207 *(\ln (D))^{2}- \\
\left.0.0281 *(\ln (D))^{3}\right)\end{array}$ & $5-156$ & 0.97 & $\begin{array}{l}\text { Indonesia, Kamboja, India, } \\
\text { Malaysia, Brazil, } \\
\text { Venezuela, Mexico, Costa } \\
\text { Rica, Puerto Rico, } \\
\text { Australia, and New } \\
\text { Guinea. }\end{array}$ & 2,410 \\
\hline $\begin{array}{l}\text { Manuri et al. } \\
\text { (2013) }\end{array}$ & $\left(0.242 * D^{\left.2.473 * W D^{0.736}\right)}\right.$ & $2-167$ & 0.97 & $\begin{array}{l}\text { Kapuas Hulu (West } \\
\text { Kalimanta) }\end{array}$ & 148 \\
\hline $\begin{array}{l}\text { Jaya et al. } \\
(2007)\end{array}$ & $0.107 * D^{2.486}$ & $2-35$ & 0.90 & Central Kalimantan & - \\
\hline $\begin{array}{l}\text { Brown et al. } \\
\text { (1997) }\end{array}$ & $\begin{array}{l}A G B_{\text {est }}=13.2579-4.8945 * D \\
+0.6713\left(D^{2}\right)\end{array}$ & $5-148$ & 0.97 & $\begin{array}{l}\text { Pantropical forest, } \\
\text { including lowland } \\
\text { dipterocarp forest of Asia } \\
\text { and Latin America }\end{array}$ & 69 \\
\hline
\end{tabular}

Table 3. Comparison of allometric test results

\begin{tabular}{cccccc}
\hline \multirow{2}{*}{ Growth Stage } & $\begin{array}{c}\text { Total Area } \\
\text { (ha) }\end{array}$ & $\begin{array}{c}\text { Chave et al. } \\
(\mathbf{2 0 0 5})\end{array}$ & $\begin{array}{c}\text { Manuri et al. } \\
(\mathbf{2 0 1 3})\end{array}$ & Jaya et al. (2007) & $\begin{array}{c}\text { Brown et al. } \\
(\mathbf{1 9 9 7 )}\end{array}$ \\
\cline { 3 - 6 } Tree & 1.916 & 125.65 & 128.16 & 88.37 & 77.93 \\
Pole & 0.958 & 29.67 & 33.75 & 23.61 & 23.73 \\
Sapling & 0.07 & 9.62 & 11.92 & 7,35 & 6.92 \\
\hline Total & & 164.93 & 173.83 & 119.33 & 108.58 \\
\hline
\end{tabular}

The comparisons show the allometric model by Chave et al. (2005) is $~ 5 \%$ below that of Manuri et al. (2013), yet $\sim 38 \%$ and $56 \%$ above the model produced by Jaya et al. (2007) and Brown et al. (1997), consecutively (Fig. 4). Each forest carbon assessment freely to calculate the biomass results using these allometric equations. However, the most appropriate approach will produce better carbon estimation (Roxburgh et al. 2015; Zhao et al. 2012). Chave's equation gave a better matched criteria approach and demonstrated intermediate values, a more reasonable amount of biomass, and carbon estimation.

\subsection{Species Density and Richness}

The results showed that the density for each type varied. At the tree stage, the highest density per hectare was Litsea garciae (30.79 trees/ha). The highest density in the pole stage was found in Hevea brasiliensis (62.63 trees/ha), and at the sapling stage, the highest density per hectare was also Hevea brasiliensis (171.43 trees/ha). Within the overall study, there are 56 tree species with 558 individuals found in this area. The dominant species found, e.g., Litsea garciae, Hevea brasiliensis, Nephelium lappaceum, Actinodaphne glabra, and Macaranga pruinosa. 


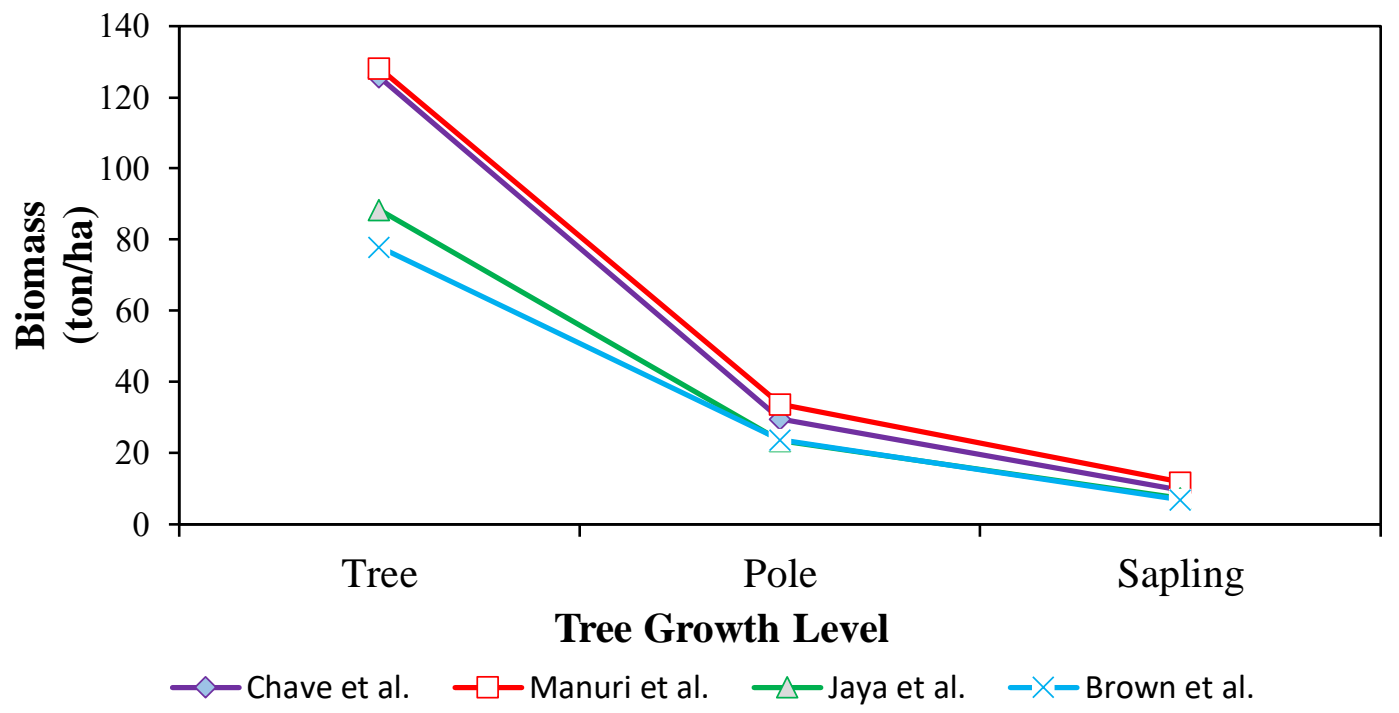

Fig. 4. Biomass comparison among several allometric models.

\section{Conclusions}

Carbon stock within the tree stage was 59.06 tons/ha $(76.18 \%)$, while the pole stage was 13.94 tons/ha (17.99\%), and the rest was at the sapling stage of 4.52 tons/ha $(5.83 \%)$. Thus, the overall carbon stored in the green open space of the Faculty of Forestry, Tanjungpura University was 77.52 tons/ha. This amount is relatively low compared to intact peatland forest, yet this carbon stock area should be well managed to enhance its function as a green open area. There were 56 tree species found, with a total of 558 individuals. Dominant tree species, namely Litsea garciae, Hevea brasiliensis, Nephelium lappaceum, Actinodaphne glabra, and Macaranga pruinosa.

\section{Acknowledgments}

The authors are very thankful and honor Tanjungpura University for permitting us to conduct this study in one of the campus green spaces.

\section{References}

Arto, I., and Dietzenbacher, E. 2014. Drivers of the Growth in Global Greenhouse Gas Emissions. Environmental Science and Technology 48(10): 5388-5394. DOI: 10.1021/es5005347

Asner, G. P., and Mascaro, J. 2014. Mapping Tropical Forest Carbon: Calibrating Plot Estimates to a Simple LiDAR Metric. Remote Sensing of Environment 140: 614-624. DOI: 10.1016/j.rse.2013.09.023

Astiani, D., Mujiman, and Rafiastanto, A. 2017. Forest Type Diversity on Carbon Stocks: Cases of Recent Land Cover Conditions of Tropical Lowland, Swamp, and Peatland Forests in West Kalimantan, Indonesia. Biodiversitas 18(1): 137-144. DOI: 10.13057/biodiv/d180119

Astiani, D., Burhanuddin, Gusmayanti, E., Widiastuti, T., and Taherdjadeh, M. 2018. Enhancing Water Levels of Degraded, Bare, Tropical Peatland in West Kalimantan, Indonesia: Impacts on $\mathrm{CO}_{2}$ Emission from Soil Respiration. Biodiversitas 19(2): 472-477. DOI: 10.13057/biodiv/d190221 
Bispo, D. F. A., Silva, A. C., Christofaro, C., Silva, M. L. N., Barbosa, M. S., Silva, B. P. C., Barral, U. M., and Fabris, J. D. 2016. Hydrology and Carbon Dynamics of Tropical Peatlands from Southeast Brazil. Catena 143: 18-25. DOI: 10.1016/j.catena.2016.03.040

Brown, S. 1997. Estimating Biomass and Biomass Change Of Tropical Forest: a Prime (FAO Forestry Paper - 134). FAO Rome.

Bustamante, M. M. C., Roitman, I., Aide, T. M., Alencar, A., Anderson, L. O., Luiz Aragao, L. A., Asner, G. P., Barlow, J, Berenguer, E., Chambers, J., Costa, M. H., Fanin, T., Ferreira, L. G., Ferreira, J., Keller, M., Magnusson, W. E., Morales-Barquero, L., Morton, Ometto, J. P. H. B., Palace, M., Peres, C. A., Silver, D., Trumbore, S., and Vieira, I. C. G. 2016. Toward an Integrated Monitoring Framework to Assess the Effects of Tropical Forest Degradation and Recovery on Carbon Stocks and Biodiversity. Global Change Biology 22: 92-109. DOI: $10.1111 / \mathrm{gcb} .13087$

BSN. 2011. SNI 7724:Pengukuran dan Penghitungan Cadangan Karbon - Pengukuran Lapangan untuk Penaksiran Cadangan Karbon Hutan (Ground Based Forest Carbon Accounting). Badan Standar Nasional (BSN), Jakarta, Indonesia.

Carlson, K. M., Curran, L. M., Ratnasari, D., Pittman, A. M., Soares-Filho, B. S., Asner, G. P., Trigg, S. N., Gaveau, D. A., Lawrence, D., and Rodrigues, H. O. 2012. Committed Carbon Emissions, Deforestation, and Community Land Conversion from Oil Palm Plantation Expansion in West Kalimantan, Indonesia. Proceedings National Academic Science USA 109: 7559-7564.

Chave, J., Andalo, C., Brown, S., Cairns, M.A., Chambers, J.Q., Eamus, D., Folster, H., Fromard, F., Higuchi, N., Kira, T., Lescure, J.P., Nelson, B.W., Ogawa, H., Puig, H., and Yamakura, T. 2005. Tree Allometry and Improved Estimation of Carbon Stocks and Balance in Tropical Forests. Oecologia 145: 87-99. DOI: 10.1007/s00442-005-0100-x

Delworth, T. L., Zeng, F., Vecchi, G. A., Yang, X., Zhang, L., and Zhang, R. 2016. The North Atlantic Oscillation as a Driver of Rapid Climate Change in the Northern Hemisphere. Nature Geoscience 9(7): 509-512. DOI: 10.1038/ngeo2738

De Villiers, C., Chen, S., Jin, C., and Zhu, Y. 2014. Carbon Sequestered in the Trees on a University Campus: A Case Study. Sustainability Accounting, Management and Policy Journal 5(2): 149-171. DOI: 10.1108/sampj-11-2013-0048

Direktorat Jenderal Penataan Ruang. 2008. Peraturan Menteri Pekerjaan Umum Nomor 05/PRT/M/2008 tentang Pedoman Penyediaan dan Pemanfaatan Ruang Terbuka Hijau di Kawasan Perkotaan. Menteri Pekerjaan Umum, Jakarta, Indonesia.

Erly, H., Wulandari, C., Safe'i, R., Kaskoyo, H., and Winarno, G. D. 2019. Species Diversity of Trees and Carbon Stock in Resort Pemerihan, Bukit Barisan Selatan National Park. Jurnal Sylva Lestari 7(2): 139-149. DOI: 10.23960/js127139-149

Hardiansyah, G., Yani, A., Rumawadi, K., Hendarto, Yenny, Sari, E. S., Sikun, K., Pambudi, E. K., Saputra, H., Yuliansyah, Listiyowati, A. I., Hutabarat, J. A., Wegscheider, S., Nusantara, R. W., Christianto, R., Haryono, Z., Normagiat, S., and Jamani, R. 2016. Forest Reference Emission Level (FREL): Tingkat Rujukan Emisi Hutan Sub-Nasional Kalimantan Barat. Pontianak.

Heriyanto NM, Priatna D, Samsoedin I.2020. Struktur Tegakan dan Serapan Karbon pada Hutan Sekunder Kelompok Hutan Muara Merang Sumatera Selatan. Jurnal Sylva Lestari 8(2): 230240. DOI: $10.23960 /$ jsl28230-240

Holdaway, R. J., McNeill, S. J., Mason, N. W. H., and Carswell, F. E. 2014. Propagating Uncertainty in Plot-based Estimates of Forest Carbon Stock and Carbon Stock Change. Ecosystems 17: 627-640. DOI: 10.1007/s10021-014-9749-5

Houghton, R. A., House, J. I., Pongratz, J., Van Der Werf, G. R., De Fries, R. S., Hansen, M. C., Le Quer, C., and Ramankutty, R. 2012. Carbon Emissions from Land Use and Land-Cover Change. Biogeosciences 9: 5125 - 5142. DOI: 10.5194/bg-9-5125-2012 
Ibes, D. C., and Forestell, C. A. 2020. The Role of Campus Greenspace and Meditation on College Students' Mood Disturbance. Journal of American College Health 68: 4. DOI: 10.1080/07448481.2020.1726926

ICRAF. Tree Functional Attributes and Ecological Database. Wood density. db.worldagroforestry.org//wd (8 January 2021)

IPCC [Intergovernmental Panel on Climate Change]. 2014. 2013 Supplement to the 2006 IPCC Guidelines for National Greenhouse Gas Inventories: Wetlands. In: Hiraishi T, Krug T, Tanabe K, Srivastava N, Baasansuren J, Fukuda N, Troxler TG (eds). Switzerland, IPCC.

Jaya A, Siregar UJ, Daryono H, and Suhartana S. 2007. Biomassa Hutan Rawa Gambut Tropika pada Berbagai Kondisi Penutupan Lahan. Jurnal Penelitian Hutan dan Konservasi Alam 4: 341- 352. DOI: 10.20886/jphka.2007.4.4.341-352

Keith, D.W., Holmes, G., Angelo, D. S., and Heidel K. 2018. A Process for Capturing $\mathrm{CO}_{2}$ from the Atmosphere. Joule 2(8): 1573-1594. DOI: 10.1016/j.joule.2018.05.006

Krisnawati, H., Adinugroho, W. C., and Imanuddin, R. 2012. Monograf Model-Model Alometrik untuk Pendugaan Biomassa Pohon pada Berbagai Tipe Ekosistem Hutan di Indonesia. Kementerian Kehutanan. Badan Penelitian dan Pengembangan Kehutanan. Pusat Penelitian dan Pengembangan Konservasi dan Rehabilitasi, Bogor, Indonesia.

Kurnianto, S., Warren, M., Talbot, J., Kauffman, B., Murdiyarso, D., and Frolking, S. 2014. Carbon Accumulation of Tropical Peatlands Over Millennia: A Modeling Approach. Global Change Biology 21(1): 431-444. DOI: 10.1111/gcb.12672

Leng, L.Y., Ahmed, O. H., and Jalloh, M. B. 2019. Brief Review on Climate Change and Tropical Peatlands. Geoscience Frontiers 10(2): 373-380. DOI: 10.1016/j.gsf.2017.12.018

Luo, H., Liu X., Anderson, B.C., Zhang, K., Li, X., Huang, B., Li, M., Mo, Y., Fan, L., Shen, Q., Chen, F., and Jiang, M. 2015. Carbon Sequestration Potential of Green Roofs using MixedSewage-Sludge Substrate in Chengdu World Modern Garden City. Ecological Indicator 49: 247-259. DOI: 10.1016/j.ecolind.2014.10.016

Manuri, S., Putra, C. A. S., and Saputra, A. D. 2011. Teknik Pendugaan Cadangan Karbon. Merang REDD+ Pilot Project-German International Cooperation, Palembang, Indonesia.

Manuri, S., Kumara, I., Kusharyono, D., and Somala, E. 2013. Pengembangan Persamaan Alometrik Lokal di Kabupaten Kapuas Hulu. Dinas Perkebunan dan Kehutanan Kabupaten Kapuas Hulu - Forclime GIZ Report.

Manuri, S., Brack, C., Nugroho, N. P., Hergoualc'h, K., Novita, N., Dotzauer, H., Verchot, L., Putra, C. A. S., and Widyasari, E. 2014. Tree Biomass Equations for Tropical Peat Swamp Forest Ecosystems in Indonesia. Forest Ecology and Management 334: 241-253. DOI: 10.1016/j.foreco.2014.08.031

Roxburgh, S. H., Paul, K. L., Clifford, D., and England, J. R. 2015 Guidelines for Constructing Allometric Models for the Prediction of Woody Biomass: How Many Individuals to Harvest? Ecosphere 6(3): 1-27. DOI: 10.1890/es14-00251.1

Santori, G., Charalambous, C., Ferrari, M. C., and Brandani, S. 2018, Adsorption Artificial Tree for Atmospheric Carbon Dioxide Capture, Purification and Compression. Energy 162: 11581168. DOI: 10.1016/j.energy.2018.08.090

Tang, Y. J., Chen, A. P., and Zhao, S. Q. 2016. Carbon Storage and Sequestration of Urban Street Trees in Beijing, China. Frontier Ecological Evolution 4:53. DOI: 10.3389/fevo.2016.00053

Waddington, J. M., Morris, P. J., Kettridge, N., Granath, G., Thompson, D. K. H., and Moore, P.A. 2015. Hydrological Feedbacks In Northern Peatlands. Ecohydrology 8: 113-127. DOI: 10.1002/eco.1493

Zhao, F., Guo, Q., and Kelly, M. 2012 Allometric Equation Choice Impacts Lidar-Based Forest Biomass Estimates: A Case Study from the Sierra National Forest, CA. Agricultural and Forest Meteorology 165: 64-72. DOI: 10.1016/j.agrformet.2012.05.019 